\title{
POLA PENGEMBANGAN KURIKULUM PESANTREN Kasus Al-Mukhlishin Mempawah Kalimantan Barat
}

\section{Lailial Muhtifah}

STAIN Pontianak Jl. Letjen. Soeprapto Nomor 19 Pontianak Kalimantan Barat 78121

Email: laily_azhar@yahoo.co.id

\begin{abstract}
ABSTRAK
Lembaga pendidikan yang memungkinkan dapat menyelenggarakan pembelajaran formal dan nonformal bahkan informal secara sekaligus adalah pesantren. Dalam sejarahnya, keterkaitan langsung antara lingkungan madrasah, keluarga dan masyarakat bahkan dengan negara telah berlangsung selama kurang lebih empat abad. Hal yang kemudian diperlukan oleh pesantren adalah merumuskan kurikulum yang jelas yang mampu melingkupi semua bentuk dan lingkungan pendidikan. Upaya tersebut telah dilakukan oleh Pesantren Al Mukhlisin Mempawah Kalimantan Barat. Penyelidikan ini bertujuan menggambarkan pola pengembangan kurikulum pesantren tersebut. Metode penyelidikan yang digunakan adalah studi kasus. Data diperoleh dari wawancara, pengamatan dan studi dokumen. Hasil penyelidikan menunjukkan bahwa pengembangan kurikulum pesantren tetap harus memperhitungkan mutu kurikulum baik dalam tahap perencanaan, pengendalian maupun penguatan. Karakter dasar kurikulum dapat dilandasi oleh karakter mukmin ulul albâb yang secara historis telah menjadi visi utama pesantren sejak abad 17. Karakter tersebut sedemikian rupa terintegrasi dalam bentuk pembelajaran madrasah, pengajian dan kehidupan nyata pemondokan santri, ustadz dan kiai (pola pengasuhan pondok pesantren).
\end{abstract}

Kata Kunci: Kurikulum, Mukmin Ulul albâb, Pesantren

\begin{abstract}
An educational institution that allows organizing formal and non-formal learning even informal at once is Pesantren. Historically, direct linkages among environment of madrasah, families and communities indeed countries have been held for more than four centuries. Thus, Pesantren needs to formulate a clear curriculum that is able to cover all forms of education and the environment. Actually, those efforts have been made by Pesantren Al Mukhlisin Mempawah West Kalimantan. This investigation aims to describe the pattern of development of the curriculum in Pesantren. It used a case study method. The data were obtained from interviews, observation and document analysis. The results indicate that the development of curriculum in Pesantren should still take into account the quality of the curriculum in the planning, control and reinforcement. The basic character of the curriculum can be based on the character of believers as Ulul albab which historically has been the primary vision of the schools since the 17th century. In addition, the character is intergrated in such a way in the form of Islamic learning, teaching and real-life boarding students, teachers and scholars (parenting boarding school).
\end{abstract}

Keywords: Curriculum, Mukmin Ulul albâb, Pesantren 


\section{PENDAHULUAN}

Pendidikan pesantren termasuk jenis pendidikan keagamaan. Pendidikan keagamaan merupakan pendidikan yang sedemikian rupa menyiapkan peserta didik untuk dapat menjalankan perannya sebagai warga negara dengan dasar penguasaan pengetahuan khusus ajaran agama yang bersangkutan (UU No 20/2003: pasal 11 ayat (6). Peraturan Pemerintah Republik Indonesia Nomor 55 Tahun 2007 tentang Pendidikan Agama dan Keagamaan pasal 14 menyatakan bahwa pendidikan keagamaan Islam dapat berbentuk pendidikan diniyah dan pesantren. Ayat (3) dalam peraturan pemerintah tersebut menjelaskan bahwa pesantren dapat menyelenggarakan satu atau berbagai satuan dan/atau program pendidikan pada jalur formal, nonformal, dan informal. Artinya, pendidikan pesantren dapat mengintegrasikan program pada jalur formal, nonformal, dan informal. Pasal 13 ayat (4) menjelaskan tentang syarat pendirian satuan pendidikan keagamaan sebagaimana yang dimaksud pada ayat (3) yakni terdiri atas: isi pendidikan, jumlah dan kualifikasi pendidik dan tentang kependidikan, sarana dan prasarana yang memungkinkan terselenggaranya kegiatan pembelajaran, sumber pembiayaan untuk kelangsungan program pendidikan sekurang-kurangnya untuk satu tahun pendidikan/akademik berikutnya, sistem evaluasi, dan manajemen dan proses pendidikan.

Program pada jalur formal, pendidikan keagamaan mencakup pendidikan diniyah dan pendidikan pesantren. Pasal 15 peraturan pemerintah di atas menyatakan bahwa pendidikan diniyah formal menyelenggarakan pendidikan ilmu-ilmu yang bersumber dari ajaran agama Islam pada jenjang Pendidikan Anak Usia Dini (PAUD), pendidikan dasar, pendidikan menengah, dan pendidikan tinggi, serta pendidikan diniyah nonformal. Pada pasal 21 ditetapkan bahwa pendidikan diniyah nonformal diselenggarakan dalam bentuk pengajian kitab, majelis taklim, Pendidikan al-Qur'an, diniyah takmiliyah, atau bentuk lain yang sejenis. Berarti pendidikan pesantren dapat menyelenggarakan program pendidikan jalur formal, wajib belajar 9 tahun dan menengah seperti pada madrasah dan sekolah. Pendidikan pesantren dapat pula menyelenggarakan program pendidikan keagamaan dengan jenis pendidikan diniyah formal dan jenis pendidikan diniyah nonformal.

Secara historis penyelenggaraan pendidikan pesantren tidak memiliki kurikulum tertulis. Kiai berperan utama sebagai kurikulum aktual yang mengarahkan program pembelajaran dan seluruh aktivitas santrinya di pesantren. Kurikulum pesantren dapat dikatakan sejalan dengan kehidupan pribadi kiai sebagai pendiri/pemimpin dan pengasuh pesantren.

Kecuali kiai, kitab kuning mempunyai peran penting dalam menentukan arah kurikulum pesantren. Kitab kuning turut memengaruhi kehidupan santri dalam membangun peradaban dan karakter Islam Indonesia. Menurut Masykur (2010: 150) kitab kuning tidak hanya merupakan karya intelektual, namun juga menjadi acuan tingkah laku santri. Kenyataan perilaku keberagamaan umat Islam Indonesia tergambarkan dalam pemahaman santri yang menjadi bahan ajar 
pokok di pesantren. Akan tetapi, pengembangan kurikulum pendidikan pesantren sebagai jalur pendidikan nonformal masih terabaikan, sehingga kualitas pendidikan pesantren dianggap kurang mencerminkan nilai-nilai ilmiah karena kurang mengindahkan budaya keberaksaraan. Pesantren dianggap hanya mengembangkan budaya lisan. Padahal, Atmaja (2010: 365) mengatakan bahwa pesantren sebagai lembaga pendidikan yang mengkaji kitab kuning sebagai "karya ilmiahnya" merupakan lembaga ilmiah. Di sini ada semacam perbedaan sudut pandang dalam memaknai kurikulum pesantren.

Undang-Undang Republik Indonesia Nomor 20 Tahun 2003 tentang Sistem Pendidikan Nasional pasal 36 ayat (2) mengamanatkan bahwa kurikulum pada semua jenjang dan jenis pendidikan dikembangkan dengan prinsip diversifikasi sesuai dengan satuan pendidikan, potensi daerah, dan peserta didik. Apabila konsep kurikulum tersebut diterapkan dalam konteks pesantren maka diversifikasi kurikulum merupakan upaya untuk menetapkan standar minimal kurikulum pesantren serta penyamaan visi dan misi berdasarkan Standar Nasional Pendidikan (SNP), agar keberadaan kurikulum formal pesantren diakui secara nasional.

Penataan ulang terhadap kurikulum pendidikan pesantren didasari oleh beberapa pertimbangan yaitu; 1) pendidikan pesantren, oleh masyarakat dianggap kurang bermutu sehingga minat orang tua untuk memasukkan anaknya ke pesantren menurun; 2) pendidikan pesantren memiliki kelemahan terutama dari faktor kepemimpinan, metodologi, dan adanya disorientasi pengembangan sumber daya manusia dan ekonomi, sehingga orang tua yang memasukkan anaknya ke pesantren identik dengan golongan ekonomi bawah; 3) masyarakat menganggap bahwa budaya akademik dan budaya ilmiah di pesantren cenderung lemah dibandingkan dengan lembaga pendidikan pada umumnya (Haedari dalam Atmaja, 2010: 359-360).

Berdasarkan permasalahan, fokus penyelidikan adalah pengembangan kurikulum Pendidikan Pesantren. Penetapan lokasi penyelidikan yaitu Pesantren Melayu al-Mukhlishin di Mempawah Kalimantan Barat, didasarkan pada pertimbangan; 1) pada umumnya pendidikan pesantren di Kalimantan Barat mayoritas dikelola oleh etnis Madura, sedikit sekali yang dikelola oleh etnis lain seperti Melayu; 2) Pendidikan Pesantren Melayu al-Mukhlishin tengah berupaya mengembangkan diri, dalam kurun tujuh tahun jumlah santri meningkat dari 18 orang menjadi 506 orang; 2) sebutan pimpinan pondok pesantrennya lebih dikenal dengan ustadz dari pada kiai. Hal ini mengandaikan bukan hanya ada perbedaan sebutan pimpinan pondok dengan umumnya pesantren-pesantren di Tanah Jawa tetapi juga menggambarkan ada arus pemikiran tertentu yang berkembang di Pesantren Mempawah Kalimantan Barat. Data diperoleh dengan mengacu pada ketentuan PP. No. 19 Tahun 2005 tentang Standar Nasional Pendidikan (SNP) terutama pada Standar Isi (SI). Penyelidikan ini bertujuan untuk mengungkap model konsep pengembangan kurikulum pesantren. Pendekatan penyelidikan menggunakan pendekatan kualitatif dengan metode studi 
kasus. Pengumpulan data dilakukan dengan wawancara, observasi, dan studi dokumentasi.

\section{PEMBAHASAN}

\section{Profil Pondok Pesantren Melayu Al-Mukhlishin}

Secara geografis, pondok pesantren terletak di Desa Antibar Kecamatan Mempawah Timur Kabupaten Pontianak Kalimantan Barat. Lokasi tersebut berada di sebuah daerah pedesaan, jauh dari kebisingan kota, dengan jarak tempuh dari jalan raya $\pm 3000 \mathrm{~m}$ (masyarakt setempat menyebutkan lokasi tersebut dengan petunjuk "sebelum SMK Pertanian").

Pondok pesantren ini dirintis oleh Bapak H. Mahmud AB yang berstatus sebagai ketua madrasah saat itu. Ketua madrasah merupakan salah satu kegiatan dari "divisi pendidikan" di Masjid Al-Mukhlisin pada tahun 2000-an. Setelah dilakukan pembenahan keorganisasian, lembaga tersebut dikukuhkan menjadi badan hukum. Di bawah payung badan hukum "Lembaga Pendidikan Islam AlMukhlishin" yang diketuai Bapak H. Mahmud AB dan Pondok Pesantren AlMukhlishin di pimpin Ustaz Zakaria dengan ketua dewan penasehat Bapak Drs. H. Ria Norsan, MM, MH. (Bupati Kab. Pontianak periode 2009-2014) dan ketua dewan pembina Bapak Supardi AK, S.Pd., M.H., pondok pesantren tersebut semakin aktif dalam berbagai kegiatan pelayanan umat di bidang pendidikan dan sosial kemasyarakatan. Pondok Pesantren tersebut semakin dikenal luas.

Motto Pondok Pesantren Al-Mukhlishin adalah Kreatif, Tertib, Sopan, Panutan (KTSP). Visinya "membentuk generasi Islam yang berwawasan religius dan kebangsaan menuju masyarakat madani”. Misi pesantren tersebut, yaitu: 1) terwujudnya generasi Islam yang berilmu, berakhlak dan berwawasan kebangsaan; 2) terwujudnya generasi Islam yang Qurani, kreatif, dan berdikari; dan 3) terwujudnya generasi Islam yang unggul dan berprestasi. Tujuan berdirinya, yakni; 1) meningkatkan kehidupan beragama, berbangsa, dan bernegara; 2) menyukseskan program pemerintah wajib belajar 9 tahun; 3) menyelenggarakan program dakwah Islamiyah dengan konsep menjaga nilai-nilai persatuan dan kesatuan umat; 4) mencetak generasi muda yang berwibawa, berilmu, berakhlak mulia, dan berwawasan kebangsaan; dan 5) mencetak generasi yang terampil dan memiliki keterampilan.

Sistem pendidikan Pondok Pesantren Al-Mukhlisin Mempawah Kalimantan Barat adalah mengintegrasikan sistem pendidikan formal sesuai kurikulum pemerintah (MI, MTS, dan MA) dengan sistem Pendidikan Diniyah Nonformal melalui pengajian kitab kuning yang bertingkat (Ûlâ, Wusthâ, dan 'Ulyâ). Pengembangan diri diberikan kepada para santri melalui; 1) latihan pidato dan khatib dengan menggunakan bahasa Arab, bahasa Inggris dan bahasa Indonesia; 2) pembinaan bacaan shalawat, qâri' dan qâri'ah; 3) pelatihan seni nasyid, kasidah, dan kaligrafi; 4) pramuka; 5) agro industri; 6) olah raga dan bahasa Arab; 7) kursus komputer; dan 8) kursus bahasa Inggris. 
Staf pengajar pesantren terdiri atas; 1) Ust. Zakaria. MS, S.HI. (Pondok Salafiyah dan S1 STIS Pontianak), 2) Ust. Mulyadi Afwani, S.Ag. (Pondok Modern Wali Songo Ngabar Ponorogo Jawa Timur dan S1 UIN Sunan Kalijaga Yogyakarta), 3) Firmansyah, S. HI., M. Pd.I. (Pondok Dalwa, S1 STAI Dalwa Bangil dan S2 IAIN Sunan Ampel Surabaya), 4) Ust. Burhan (Pondok Modern Wali Songo Ngabar Ponorogo Jawa Timur), 5) Ust. Supiandi, S. Pd.I. (alumni Pondok Dalwa Bangil dan S1 STAI Dalwa Jawa Timur), 6) Ust. Muzayyin, S. Pd.I. (Pondok Dalwa Bangil dan S1 STAI Dalwa Jawa Timur), 7) Ust. Ahmad Yani (alumni PGA dan Pondok Salafiyah), 8) Ust. M. Alif (Pondok Modern Assakinah Jawa Barat), 9) Ust. Rawin Dauzen (Pondok Modern Assakinah Jawa Barat), 10) Zainal bahri, S.Pd. (S1 Universitas Terbuka)

\section{Pola Pengembangan Kurikulum Pondok Pesantren Melayu al-Mukhlishin Mempawah Kalimantan Barat}

Menurut Muhaimin (2010: 1) kurikulum dapat diartikan sebagai jalan terang yang mesti dilalui oleh pendidik/guru dan peserta didik untuk mengembangkan pengetahuan, keterampilan, sikap, serta nilai-nilai. Pengembangan kurikulum Pendidikan Agama Islam (PAI) dapat diartikan sebagai; (a) kegiatan menghasilkan kurikulum PAI; (b) proses mengaitkan satu komponen dengan yang lainnya untuk menghasilkan kurikulum PAI yang lebih baik; dan/atau (c) kegiatan penyusunan (desain), pelaksanaan, penilaian, dan penyempurnaan kurikulum PAI (Muhaimin, 2010: 10).

Pola pengembangan kurikulum Pondok Pesantren Melayu al-Mukhlishin Mempawah Kalimantan Barat dapat dianalisis berdasarkan teori peningkatan mutu kurikulum yang mencakup beberapa fungsi, yaitu: perencanaan, pengendalian, peningkatan mutu (Juran, 1989: 15).

\section{a. Perencanaan}

Perencanaan pengembangan kurikulum Pondok Pesantren Melayu alMukhlishin Mempawah Kalimantan Barat didasarkan pada kriteria manajemen mutu pendidikan. Konsep mutu dalam perspektif CPE (Continuing Professional Education) dibangun berdasarkan pengalaman dan pengembangan strategi yang jelas disertai pemahaman tentang mutu aktual (Tovey, 1994: 13). Konsep mutu ini dapat digunakan dalam mengembangkan mutu pendidikan Islam berdasarkan pengalaman-pengalaman yang diperoleh dalam penyelenggaraan pendidikan Islam, khususnya berdasarkan pengembangan strategi dan karakter yang dibangun di dunia pesantren. Manajemen mutu dalam perspektif pemimpin dan manajer adalah kombinasi dari sistem-sistem untuk memastikan adanya penyerahan tentang apa yang dijanjikan. Menurut ISO 8402-1986, manajemen mutu merupakan aspek-aspek fungsi manajemen secara keseluruhan untuk menentukan dan menerapkan kebijakan mutu (Apendix ISO 8402 - 1986: 15).

Kegiatan perencanaan pengembangan kurikulum di Pesantren AlMukhlisin pun dapat dianalisis berdasarkan teori perencanaan mutu Juran yang mencakup; (a) menetapkan tujuan mutu, (b) mengidentifikasi pelanggan, (c) 
menentukan kebutuhan pelanggan, (d) mengembangkan keistimewaan lulusan yang merespons kebutuhan lulusan, dan (e) mengembangkan proses yang mampu menghasilkan keistimewaan lulusan. Rincian kegiatan perencanan kurikulum tersebut yaitu;

Tabel Perencanaan Pengembangan Kurikulum PesantrenAl Mukhlisin Mempawah Kalimantan Barat

\begin{tabular}{|c|c|c|c|}
\hline No & Kriteria & Kegiatan & Keterangan \\
\hline A. & $\begin{array}{l}\text { Menyusun rencana } \\
\text { pengembangan }\end{array}$ & - & Belum dilaksanakan \\
\hline B. & Membentuk tim & - & Belum dilaksanakan \\
\hline C. & $\begin{array}{l}\text { Memfasilitasi analisis } \\
\text { konteks }\end{array}$ & - & Belum dilaksanakan \\
\hline D. & $\begin{array}{l}\text { Mengidentifikasi muatan } \\
\text { lokal }\end{array}$ & $\begin{array}{l}\text { Dilakukan melalui rapat } \\
\text { tahunan yang dihadiri oleh } \\
\text { pimpinan pesantren, panitia, } \\
\text { para asâtidz dan staf } \\
\text { administrasi. }\end{array}$ & $\begin{array}{l}\text { Struktur kurikulum } \\
\text { muatan lokal }\end{array}$ \\
\hline E. & $\begin{array}{l}\text { Menentukan kebutuhan } \\
\text { pengembangan diri santri }\end{array}$ & $\begin{array}{l}\text { Dilakukan melalui rapat } \\
\text { tahunan yang dihadiri oleh } \\
\text { pimpinan pesantren, panitia, } \\
\text { para asâtidz dan staf } \\
\text { administrasi. }\end{array}$ & $\begin{array}{l}\text { Struktur kurikulum } \\
\text { pengembangan diri } \\
\text { santri }\end{array}$ \\
\hline F. & $\begin{array}{l}\text { Mengembangkan } \\
\text { keistimewaan/keunggulan } \\
\text { lokal dan global }\end{array}$ & $\begin{array}{l}\text { Dilakukan melalui rapat } \\
\text { tahunan yang dihadiri oleh } \\
\text { pimpinan pesantren, panitia, } \\
\text { para asâtidz dan staf } \\
\text { administrasi. }\end{array}$ & $\begin{array}{l}\text { Program muatan } \\
\text { lokal dan progran } \\
\text { pengembangan diri } \\
\text { santri }\end{array}$ \\
\hline G. & $\begin{array}{l}\text { Mengembangkan proses } \\
\text { yang menghasilkan } \\
\text { keistimewaan/keunggulan } \\
\text { santri }\end{array}$ & $\begin{array}{l}\text { 1. Pembelajaran kitab } \\
\text { kuning di kelas. } \\
\text { 2. Praktik pembelajaran } \\
\text { kitab kuning di luar kelas. } \\
\text { 3. Pemberian kosa kata B. } \\
\text { Arab. } \\
\text { 4. Babtsul kitâb/Hadis. } \\
\text { 5. Tahsinul lughah. } \\
\text { 6. Kursus-kursus (kaligrafi, } \\
\text { musik, tilawah, qasidah, } \\
\text { dan nasyid). } \\
\text { 7. Shalat berjamaah di } \\
\text { masjid. (pembacaan } \\
\text { 8. Shalawat } \\
\text { asmâul husna). } \\
\text { 9. Qirâat al-Qur'an } \\
\text { perkelompok } \\
\text { pertingkatan. } \\
\text { 10. Shalat tabajjud berjamaah. } \\
\text { 11. Shalat dluba. }\end{array}$ & $\begin{array}{l}\text { Terjadwal dalam } \\
\text { kegiatan sehari-hari } \\
\text { santri. }\end{array}$ \\
\hline
\end{tabular}




\begin{tabular}{|c|c|c|c|}
\hline No & Kriteria & Kegiatan & Keterangan \\
\hline H. & $\begin{array}{l}\text { Menetapkan pengendalian } \\
\text { proses, menerjemahkan } \\
\text { rencana ke kegiatan } \\
\text { operasi . }\end{array}$ & $\begin{array}{l}\text { Melalui rapat kerja dan } \\
\text { evaluasi tahuan yang dihadiri } \\
\text { oleh pimpinan pesantren, } \\
\text { para asâtidz, panitia dan staf } \\
\text { administrasi }\end{array}$ & $\begin{array}{l}\text { Belum } \\
\text { terdokumentasi. }\end{array}$ \\
\hline I. & $\begin{array}{l}\text { Menyusun dan } \\
\text { mengembangkan KTSP } \\
\text { pesantren }\end{array}$ & $\begin{array}{l}\text { 1. Visi, misi, tujuan } \\
\text { pesantren } \\
\text { 2. Struktur dan muatan } \\
\text { kurikulum } \\
\text { 3. Silabus. } \\
\text { 4. RPP. } \\
\end{array}$ & $\begin{array}{l}\text { Belum } \\
\text { terdokumentasi. }\end{array}$ \\
\hline J. & $\begin{array}{l}\text { Memfinalkan, menetapkan } \\
\text { KTSP dan dokumen } \\
\text { pendukung }\end{array}$ & 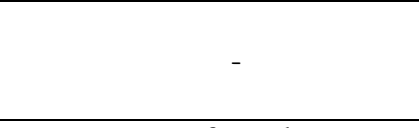 & Belum terlaksana \\
\hline $\mathrm{K}$. & $\begin{array}{l}\text { Analisis standar isi dan } \\
\text { Standar Kompetensi } \\
\text { Lulusan (SKL) pesantren } \\
\text { dan pengembangannya }\end{array}$ & Non formal & $\begin{array}{l}\text { Dilaksanakan secara } \\
\text { tidak langsung atau } \\
\text { non formal. } \\
\text { Belum } \\
\text { terdokumentasi. }\end{array}$ \\
\hline
\end{tabular}

(Sumber: hasil wawancara dengan pimpinan pondok, para asâtidz dan staf administrasi pada tanggal 5 dan 6 Maret 2012)

Berdasarkan data di atas dapat diketahui bahwa enam dari sebelas kriteria perencanaan mutu pengembangan kurikulum pendidikan pesantren AlMukhlisin terpenuhi. Berarti, perencanaan mutu pengembangan kurikulum di pondok pesantren tersebut tertib administrasi namun cenderung belum optimal. Kondisi ini disebabkan oleh beberapa faktor, yakni: a) KTSP di pendidikan pesantren tersebut belum pernah disosialisasikan, b) para asâtidz dan jajaran pimpinan pesantren belum pernah diikutkan workshop KTSP, dan c) Pimpinan pesantren belum pernah menyelenggarakan pelatihan untuk meningkatkan kompetensi para asâtidz, seperti workshop, in house training, dan diklat penyusunan KTSP, pendekatan pembelajaran PAIKEM, dan penilaian berbasis kelas.

\section{b. Pengendalian}

Walaupun Kurikulum Tingkat Satuan Pendidikan (KTSP) di Pondok Pesantren Al-Mukhlisin belum disosialisasikan dan belum terdokumentasikan, namun pimpinan pesantren melakukan pengendalian terhadap kurikulum yang analisisnya dapat ditelaah berdasarkan teori manajemen mutu pendidikan Juran dengan tahapan kegiatan yaitu: (a) mengevaluasi kinerja aktual, (b) membandingkan kinerja aktual, dan (c) Pimpinan pondok pesantren bertindak menangani perbedaan/menyelesaikan pertentangan.

Proses evaluasi kinerja aktual didasarkan pada komponen-komponen konteks, input, proses, output, dan outcome yang satu sama lain saling terkait secara sistematis. Evaluasi imput menekankan pada ketersediaan dan kesiapan input sebagai prasyarat berlangsungnya proses. Hasil evaluasi mengenai visi, misi, dan 
tujuan pendidikan di pesantren tersebut telah tersusun, namun sasarannya belum dirumuskan. Sumber daya manusia seperti ustadz tersedia dan pada umumnya berasal dari pondok pesantren juga, namun mereka belum pernah menerima sosialisasi dan pelatihan penyusunan KTSP. Sumber daya lainnya seperti uang, peralatan, perlengkapan dan bahan-bahan yang dibutuhkan para santri cukup tersedia. Input manajemen (tugas, rencana, dan program kerja) terumuskan dengan baik. Aspek regulasi (ketentuan, limitasi, dan prosedur kerja) belum terdokumentasi.

Evaluasi proses diselenggarakan saat proses pembelajaran di kelas dan di luar kelas. Hasilnya, pedoman kerja cenderung hanya berdasarkan input yang terkait dengan tugas, rencana, dan program kerja pendidikan pesantren, bukan berdasarkan dokumen KTSP, silabus dan RPP.

Membandingkan kinerja aktual dilakukan melalui evaluasi dalam rapat tahunan yang dihadiri oleh pimpinan pendidikan/pondok pesantren, para asâtidz, dan staf administrasi. Hasilnya menunjukkan ada peningkatan baik secara kualitas maupun kuantitas setelah dilakukan rapat tahunan.

Salah satu tindakan pimpinan pendidikan/pondok pesantren dalam menangani setiap perbedaan dan permasalahan terjadi saat ada santri yang tidak lulus imtahan nihaya dan ada santri yang berasal dari SMP dan SMA yang kurang memiliki dasar ilmu agama. Jumlah santri yang tidak lulus tersebut $\pm 20 \%$. Penanganan terhadap santri yang tidak lulus dilakukan dengan cara memanggil santri tersebut ke sekretariat untuk diberikan penyadaran, pemahaman, dan peringatan tentang aturan dan target-target pembelajaran di pesantren tersebut. Penanganan dapat dikatakan berhasil ketika santri mengalami kemajuan dalam pembelajaran dan tuntas dalam pembelajaran. Ketika santri yang berasal dari SMP dan SMA mengaji kitab kuning, diberikan kitab yang ada terjemahan dengan bahasa Indonesia. Para santri yang berasal dari MTs dan MA diberi kitab kuning yang tidak ada terjemahannya. Jadi, ada perlakuan yang berbeda terhadap para santri sesuai dengan latar belakang, potensi dan prestasi mereka.

\section{c. Peningkatan}

Kegiatan peningkatan mutu pengembangan kurikulum di Pesantren AlMukhlisin mengacu pada konsep "tarbiyah mukmin ulul albâb”. Konsep tersebut memiliki beberapa langkah yaitu; 1) menguji kebutuhan santri, 2) menetapkan infrastruktur untuk pengembangan kurikulum, 3) mengidentifikasi kegiatan peningkatan mutu, 4) menetapkan tim pengembangan kurikulum, 5) menyediakan tim dengan sumber daya, pelatihan, dan motivasi untuk mendiagnosis penyebab dan upaya untuk mengatasinya, dan 6) menetapkan pengendalian pengembangan kurikulum agar tetap pada jalurnya.

Pertama, kegiatan menguji kebutuhan santri, penekanannya pada kebutuhan akan kitab. Pondok pesantren Al-Mukhlisin melakukan pengadaan kitab kuning terkait dengan mata pelajaran al-Qur'an, Hadis, Tauhid, Fiqih, Akhlak, SKI, dan Bahasa Arab. Pembelajaran al-Qur'an menggunakan kitab 
Tafsîr Jalâlain. Pembelajaran Hadis menggunakan kitab al-Arba'in an-Nawawi dan Lubâb al-Hadits. Pembelajaran Tauhid menggunakan kitab Durûs al-Taubid dan alJawâhiru al-Kalâmiyyah, Akhlak dengan kitab al-Akhlaq Lil Banîn, Fiqih dengan kitab ad-Durûs al-Fiqhiyyah dan Fathbul Qarîb, Sejarah Kebudayaan Islam dengan kitab Khulâshotu nûr al-Yaqîn, dan Bahasa Arab dengan kitab al-Jurûmiyah. Kitab kuning yang tidak ada terjemahannya dibimbing langsung oleh para asatidz. Santri tingkat Ûlâ, Wusthâ, dan 'Ûlyâ yang berasal dari SMP dan SMA menggunakan kitab dengan terjemahan. Santri tingkat Ûlâ, Wusthâ, dan 'Ûlyâ yang berasal dari Madrasah Tsanawiyah dan Madrasah Aliyah menggunakan kitab kuning tanpa terjemahan.

Kedua, mengadakan dan menetapkan infrastruktur yang terkait dengan pengembangan kurikulum dilakukan melalui pengadaan kitab kuning, pengadaan sarana belajar seperti infokus/LCD dan laptop. Untuk Khatt al Qur'ân melalui pengadaan alat peraga (khandam).

Ketiga, mengidentifikasi kegiatan peningkatan mutu belum pernah dilakukan. Pesantren hanya menunggu undangan workshop atau pelatihan dari Kementerian Agama Pusat, Propinsi, atau Kabupaten Pontianak.

Keempat, belum pernah ditetapkan tim pengembangan kurikulum.

Kelima, berupaya menyediakan tim pengembangan kurikulum dengan sumber daya yang ada namun disertai dengan pelatihan dan dimotivasi untuk selalu bersemangat dalam mengembangkan kurikulum. Pimpinan pondok pesantren selalu memotivasi untuk senantiasa mengembangkan dan mengubah kurikulum sesuai dengan perubahan zaman. Pada tahun 2005-2010, kajian kitab terbatas hanya pada tiga mata pelajaran, yakni yang berkaitan dengan al-Qur'an, Hadis, Fiqih, dan Bahasa Arab. Pada tahun 2010 sampai dengan sekarang, telah ditetapkan penambahan kajian kitab yang disesuaikan dengan kurikulum mata pelajaran Pendidikan Agama Islam (PAI), yakni: 1) al-Qur'an, 2) Hadis, 3) Tauhid, 4) Fiqih, 5) Akhlak, 6) Sejarah Kebudayaan Islam, dan 7) Bahasa Arab.

Keenam, menetapkan pengendalian kurikulum agar tetap pada jalurnya dilakukan melalui rapat yang dilaksanakan setiap tahun sekali pada awal tahun ajaran baru.

\section{d. Evaluasi}

Kegiatan penilaian dan penyempurnaan kurikulum pondok pesantren dilakukan untuk pertama kalinya pada bulan Juni tahun 2010. Kegiatan tersebut belum melibatkan pakar, guru, peserta didik dan masyarakat pengguna demi mengidentifikasi tujuan pondok pesantren Al-Mukhlisin dan cara-cara mencapainya. Kegiatan tersebut dilaksanakan oleh panitia yang terdiri atas pimpinan pondok dan hanya beberapa asâtidz yang ditunjuk. Kegiatan tersebut menghasilkan kurikulum baru (tahun 2010). Setelah disempurnakan ada perubahan orientasi pembelajaran dari penekanan pada hafalan dan daya ingat atas teks-teks ajaran Islam kepada cara berpikir empiris, historis dan kontekstual dalam memahami dan menjelaskan ajaran dan nilai-nilai agama Islam. 


\section{Struktur Kurikulum}

Kurikulum Pondok Pesantren Al Mukhlisin menunjukkan bahwa kerangka dasar kurikulum dikelompokan ke dalam dua mata pelajaran pokok yaitu Mata Pelajaran Agama Islam dan Akhlak Mulia. Pendidikan pesantren tersebut juga menyatakan bahwa mereka menyelenggarakan pendidikan diniyah secara terpadu dengan jenis pendidikan pada umumnya dengan fokus pada jenjang pendidikan anak usia dini (PAUD), pendidikan dasar, menengah, dan/atau pendidikan tinggi. Struktur kurikulum menekankan pada pendidikan diniyah nonformal dalam bentuk pengajian kitab yang diselenggarakan secara berjenjang, sesuai dengan Peraturan Pemerintah Republik Indonesia No. 55 Tahun 2007, pasal 21 ayat 1, pasal 22 ayat 1-3, dan pasal 26 ayat 2 dan pembelajaran bahasa Arab.

Substansi pembelajaran di Pondok Pesantren Al Mukhlisin disebut dengan Kurikulum Pendidikan Pesantren Nonformal yang ditempuh selama tiga tahun untuk Ũlâ (santri yang berasal dari Madrasah Tsanawiyah) dan selama tiga tahun untuk Wusthâ (santri yang berasal dari Madrasah Aliyah). Untuk tingkat Ulyâ/Takhashshus tidak ditentukan secara kaku.

\section{Struktur Kurikulum Diniyah Pesantren Al-Mukhlishin Mempawah Kalimantan Barat}

\begin{tabular}{|c|c|c|c|}
\hline Komponen & $\hat{U} 1 \hat{a}$ & Wusthâ & $\begin{array}{c}\text { 'Ulyâ } \\
\text { (Takhashshus) }\end{array}$ \\
\hline \multicolumn{4}{|l|}{ A. Kajian Kitab: } \\
\hline 1. Al-Qur'an & 2 & 2 & 2 \\
\hline 2. Hadis & 2 & 2 & 2 \\
\hline 3. Aqidah & 2 & 2 & 2 \\
\hline 4. Akhlak & 2 & 2 & 2 \\
\hline 5. Fiqih & 2 & 2 & 2 \\
\hline 6. SKI & 2 & 2 & 2 \\
\hline B. Bahasa Arab & 3 & 3 & 3 \\
\hline \multicolumn{4}{|l|}{ C. Muatan Lokal } \\
\hline 1. Kaligrafi & 4 & 4 & 4 \\
\hline 2. Tundang & 2 & 2 & 2 \\
\hline \multicolumn{4}{|l|}{ D. Pengembangan Diri: } \\
\hline 1. Seni Tilawah & 2 & 2 & 2 \\
\hline 2. Tahfidz & 2 & 2 & 2 \\
\hline 3. Qasidah/ Nasyid & 2 & 2 & 2 \\
\hline 4. Pidato 3 bahasa & 2 & 2 & 2 \\
\hline 5. Khatib & 2 & 2 & 2 \\
\hline 6. Fardhu Kifayah & 2 & 2 & 2 \\
\hline 7. Bilal & 2 & 2 & 2 \\
\hline Jumlah & 34 & 34 & 34 \\
\hline
\end{tabular}

(Sumber: Jadwal pembelajaran dan hasil wawancara dengan pimpinan dan para ustad $₹$, tanggal 20 Pebruari 2012).

Ketuntasan belajar yang ditentukan di pondok pesantren berkisar antara 65-100\%. Kriteria ideal ketuntasan untuk masing-masing kajian kitab dan 
bahasa Arab adalah 65\%. Kenaikan kelas dan kelulusan ditentukan dengan sistem Imtihân Nihâya.

Standar kompetensi lulusan dan kompetensi kajian kitab dan bahasa Arab lebih menekankan pada pengembangan kemampuan, pengetahuan, dan keterampilan santri untuk menjadi ahli ilmu agama Islam (mutafaqqih fi ad-dîn) melalui penguasaan kitab kuning dan bahasa Arab.

\begin{tabular}{|c|c|c|}
\hline \multicolumn{3}{|c|}{$\begin{array}{l}\text { Standar Kompetensi Lulusan, Pengajian Kitab dan Mata Pelajaran } \\
\text { Bahasa Arab di Pesantren al-Mukhlishin Mempawah Kalimantan Barat }\end{array}$} \\
\hline No. & Komponen & $\begin{array}{c}\text { Standar Kompetensi Lulusan dan Kompetensi } \\
\text { Mata Pelajaran }\end{array}$ \\
\hline A. & $\begin{array}{l}\text { Kajian Kitab: } \\
\text { 1. Al-Qur'an } \\
\text { 2. Hadis } \\
\text { 3. Tauhid } \\
\text { 4. Akhlak } \\
\text { 5. Fiqih } \\
\text { 6. SKI }\end{array}$ & $\begin{array}{l}\text { Santri menguasai kajian kitab (al-Qur'an, Hadis, tauhid, } \\
\text { akhlak, fiqih dan sejarah kebudayaan Islam). }\end{array}$ \\
\hline B. & Bahasa Arab & $\begin{array}{l}\text { Santri terampil bermuhadasah, dan memahami kaidah- } \\
\text { kaidah Bahasa Arab dasar. }\end{array}$ \\
\hline
\end{tabular}

Beban belajar santri yaitu meliputi kegiatan tatap muka per jam pembelajaran ditetapkan berlangsung selama 30 menit. Beban belajar kegiatan tatap muka per minggu di pondok pesantren tersebut ditetapkan berlangsung selama 2 jam pembelajaran. Beban ini untuk kajian kitab: al-Qur'an, Hadis, Tauhid, Akhlak, Fiqih, Sejarah Kebudayaan Islam, muatan lokal (tundang), dan pengembangan diri. Beban belajar kegiatan tatap muka per minggu untuk mata pelajaran Bahasa Arab adalah 3 jam pembelajaran. Beban belajar kegiatan tatap muka per minggu untuk mata pelajaran muatan lokal kaligrafi adalah 4 jam pembelajaran.

Kurikulum Tingkat Satuan Pendidikan (KTSP) di Pondok Pesantren alMukhlisin mencakup; 1) komponen KTSP; tujuan pendidikan pesantren, struktur dan muatan kurikulum, serta kalender pendidikan; 2) pengembangan silabus; dan 3) pelaksanaan penyusunan KTSP pendidikan pesantren.

Kalender pendidikan Kurikulum Pondok Pesantren Melayu al-Mukhlishin Mempawah Kalimantan Barat ini diselenggarakan dengan mengikuti kalender pendidikan formal (madrasah) setiap tahun ajaran. Kalender pendidikan ditentukan berdasarkan alokasi waktu dan penetapan kalender pendidikan. 
Alokasi Waktu Kalender Pendikan Pesantren Al-Mukhlishin Mempawah Kalimantan Barat

\begin{tabular}{|c|c|c|c|}
\hline No & Kegiatan & Alokasi Waktu & Keterangan \\
\hline 1. & $\begin{array}{l}\text { Minggu efektif } \\
\text { belajar }\end{array}$ & $\begin{array}{l}\text { Minimum } 34 \text { minggu } \\
\text { dan maksimum } 38 \\
\text { minggu }\end{array}$ & $\begin{array}{l}\text { Pembelajaran efektif di Pendipes } \\
\text { (Januari s/d Juni dan Juli s/d } \\
\text { Desember) }\end{array}$ \\
\hline 2. & $\begin{array}{l}\text { Jeda tengah } \\
\text { semester }\end{array}$ & $\begin{array}{l}\text { Maksimum } 2 \text { minggu } \\
\text { (Desember s/d Januari) }\end{array}$ & Satu minggu setiap semester \\
\hline 3. & Jeda antar semester & $\begin{array}{l}\text { Maksimum } 2 \text { minggu } \\
\text { Juni s/d Juli dan } \\
\text { Desember s/d Januari) }\end{array}$ & Antara semester I dan II \\
\hline 4. & $\begin{array}{l}\text { Libur akhir tahun } \\
\text { pelajaran }\end{array}$ & $\begin{array}{l}\text { Maksimum } 3 \text { minggu } \\
\text { Juni s/d Juli) }\end{array}$ & $\begin{array}{c}\text { Digunakan untuk penyiapan } \\
\text { kegiatan dan administrasi akhir } \\
\text { dan awal tahun }\end{array}$ \\
\hline 5. & $\begin{array}{l}\text { Hari libur } \\
\text { keagamaan }\end{array}$ & Tiga minggu & $\begin{array}{c}\text { Sepuluh hari sebelum hari raya } \\
\text { Idul Fitri dan sepuluh hari } \\
\text { sesudah hari raya }\end{array}$ \\
\hline 6. & $\begin{array}{l}\text { Hari libur } \\
\text { umum/nasional }\end{array}$ & Tidak libur & $\begin{array}{c}\text { Kegiatan pembelajaran di } \\
\text { Pendipes } \\
\text { tetap berlangsung }\end{array}$ \\
\hline 7. & Hari libur khusus & Tidak libur & Tidak ada hari libur khusus \\
\hline 8. & $\begin{array}{l}\text { Kegiatan khusus } \\
\text { Pendipes }\end{array}$ & $\begin{array}{l}\text { Satu minggu (Minggu } \\
\text { ke-3/4 bulan Juni) }\end{array}$ & $\begin{array}{c}\text { Diisi dengan kegiatan porseni } \\
\text { bidang agama seperti } \\
\text { pertandingan ceramah, tilawah, } \\
\text { qasidah dan nasyid, kaligrafi dan } \\
\text { lain-lain termasuk kegiatan olah } \\
\text { raga. }\end{array}$ \\
\hline
\end{tabular}

(Sumber: Hasil wawancara dengan pimpinan pendikan pesantren dan jadwal pengajian kitab)

Penetapan permulaan tahun ajaran mengikuti kalender pendidikan madrasah, yakni bulan Juli setiap tahun dan berakhir pada bulan Juni tahun berikutnya. Hari libur Pendidikan Pesantren al-Mukhlisin ditetapkan berdasarkan keputusan Menteri Pendidikan Nasional dan Menteri Agama Republik Indonesia. Kegiatan belajar mengajar dilaksanakan di kelas dan di luar kelas (praktik wudhu dan shalat). Materi pembahasan pengajian kitab di lembaga tersebut dilaksanakan oleh para asâtidz. Kegiatan tersebut meliputi aspek: 1) pra pembelajaran, 2) kegiatan inti pembelajaran, dan 3) kegiatan penutup.

Berdasarkan hasil observasi dan wawancara diperoleh gambaran tentang pelaksanaan pra pembelajaran yang biasa diawali dengan pemberian kosa kata bahasa Arab. Kegiatan ini berlangsung selama kurang lebih 15 menit sebelum berlangsungnya pembelajaran. Pemateri adalah OP2M (Organisasi Pondok Pesantren al-Mukhlishin). Pra pembelajaran tersebut dilaksanakan setiap malam Senin, Selasa, Rabu, dan Kamis. Waktu pembelajaran di mulai pukul 19.30 21.30 WIB. Dalam pelaksanaan pra pembelajaran, para asatidz selalu memeriksa kesiapan para santri dalam mengikuti pembelajaran dan melakukan kegiatan apersepsi. Apersepsi diisi dengan kegiatan mengulang materi pembelajaran yang 
sudah diberikan pada malam sebelumnya, memperkenalkan pelajaran baru, serta memotivasi mereka untuk belajar.

Dari hasil pegamatan dan wawancara ditemukan bahwa kegiatan inti pembelajaran mencakup: penguasaan materi pembelajaran, pengaitan materi dengan pengetahuan lain yang relevan, menyampaikan materi dengan jelas, dan mengaitkan materi dengan realitas kehidupan. Pada umumnya, para ustadz menguasai materi yang diajarkan secara mendalam tentang topik yang mereka ajarkan serta mampu menjawab pertanyaan santri. Pada umumnya, para asâtidz, dalam menyajikan materi, selalu mengaitkan dengan kehidupan sehari-hari para santri. Contoh, pada pengajian Kitab Fiqih tentang materi wudlu' dikaitkan dengan kehidupan bersih lahir dan batin. Pada pengajian kitab sejarah kebudayaan Islam, perbuatan para sahabat diupayakan ditiru dan ditauladani dalam perilaku sehari-hari siswa. Pendekatan dan strategi pembelajaran belum bervariasi, bahkan mereka belum pernah mendapat pelatihan tentang hal itu. Karena itu, mereka belum pernah menggunakan metode pembelajaran yang bervariasi. Pada umumnya, metode yang digunakan adalah ceramah, tanya jawab, dan diskusi. Pemanfaatan media pembelajaran, hanya sebatas melalui media kitab kuning dan media alam. Contoh, pengajian kitab fiqih dengan memanfaatkan batu-batuan, kunjungan ke tempat bersejarah (mengunjungi makam Kerajaan Mempawah). Para asâtidz melaksanakan penilaian proses belajar dengan cara bertanya kepada santri secara individual dan mengawasi mereka ketika mereka berdiskusi. Penilaian hasil belajar masih belum dilakukan.

Para asâtidz merangkum hasil pembelajaran dengan melibatkan santri. Para asâtidz tidak melaksanakan tindak lanjut, misalnya dengan tugas sebagai bagian remidial, namun mereka memberikan arahan secara umum.

\section{Karakter/Nilai dalam Kurikulum}

Pendidikan karakter atau pendidikan akhlak atau pendidikan budi pekerti plus merupakan arah utama yang dituju oleh lembaga pendidikan, termasuk pendidikan pesantren. Zubaedi (2011: 15) menguraikan bahwa pendidikan karakter adalah usaha sengaja (sadar) untuk mewujudkan kebajikan, yaitu kualitas kemanusiaan yang baik secara obyektif, dan bukan hanya baik untuk individu perorangan, tetapi juga baik untuk masyarakat secara keseluruhan. Pendidikan karakter membantu manusia memahami, peduli, dan melaksanakan nilai-nilai etika inti. Pendidikan karakter adalah proses yang direncanakan, dikendalikan, dan ditingkatkan sebagai upaya mewujudkan manusia yang berkarakter/berakhlak/berbudi melalui proses pendidikan formal, nonformal, dan informal.

Pengembangan kurikulum di Pondok Pesantren Al Mukhlisin berorientasi pada pembentukan karakter santri yang berbasis pada "mukmin ulul albâb". Sumber pembentukan karakter santri "mukmin ulul albâb" adalah al-Qur'an dan hadis. 
Kata mukmin dapat ditemukan dalam teks al-Qur'an sebanyak lima belas kali di beberapa tempat dan topik yang berbeda, yaitu: dalam QS. Al-Baqarah ayat 221; QS. An-Nisa' ayat 92, 124, 93; QS. At-Taubah ayat 10; QS. Yusuf ayat 17; QS. An-Nahl ayat 97; QS. Al-Isra' ayat 19; QS. At-Taha ayat 112; QS. AlAnbiya' ayat 94; QS. Al-Ahzab ayat 36; QS. Al-Hasyr ayat 23; QS. At-Taghabun ayat 2. Kata "mukminun" disebut sebanyak 35 kali. Sedangkan kata "mukminin" muncul paling banyak, sebanyak 144 kali. Mukmin berasal dari kata-kata iman, maksudnya seseorang yang telah beriman memercayai bahwa tiada Tuhan selain Allah dan memercayai bahwa Muhammad SAW adalah utusan Allah dan seterusnya hal-hal yang wajib diimani. Orang beriman itu memercayai bahwa Allah itu Ada dan Esa, dengan segala kesempurnaan-Nya, memercayai adanya malaikat yang melaksanakan berbagai tugas yang diserahkan kepadanya, berkenaan dengan kerohanian. Memercayai kitab-kitab suci yang diturunkan Allah kepada rasul-rasul terdahulu, untuk memimpin umatnya, memercayai Rasul-rasul sepanjang zaman, sejak Adam sampai Rasul Terakhir, Muhammad SAW dan memercayai akhirat, hari pemeriksaan dan pembalasan yang adil terhadap perbuatan manusia selama hidupnya di dunia, berakhir dengan masuk surga atau neraka.

Keimanan bukan sekedar percaya, melainkan membuahkan amal saleh, perbuatan yang diridhoi Allah. Beberapa sifat mukminin dalam al-Qur'an menurut Choiruddin Hadhiri (1994: 115) adalah: orang-orang mukmin, mereka mengamalkan dan menyeru yang ma'ruf dan mencegah yang munkar (QS. AtTaubah: 71); gemetarlah hatinya jika disebut nama Allah, dan senantiasa bertambahlah imannya bila dibacakan ayat-ayat-Nya (QS. Al-Anfal: 2-4); mereka selalu menepati dan memelihara amanah dan janji-janjinya (QS. As-Sajadah: 1516); mereka memelihara shalat dan melaksanakannya dengan khusyuk (QS. AnNahl: 94-97); mereka berjihad di jalan Allah dengan harta dan jiwa mereka (QS. Al-Hujurat: 14-15), menjauhkan diri dari perkataan dan perbuatan yang tak berguna, menjaga kemaluannya/kehormatannya, menunaikan zakat, dan sebagainya (QS. As-Saff: 10-13); mereka itulah yang beriman dengan sebenarnya (QS.Al-Mu'minun: 1-11).

Istilah ulul albâb dapat ditemukan dalam teks al-Qur'an sebanyak enam belas kali yang tersebar di sepuluh surah dengan topik yang berbeda, yaitu dalam QS. Al-Baqarah ayat 179, 197, 269; QS. Ali-Imran ayat 7 dan 190; QS. AlMaidah ayat 100; QS. Yusuf ayat 111; QS. Al-Ra'd ayat 19; QS. Ibrahim ayat 52; QS. Shad ayat 29, 43; QS. Al-Zumar ayat 9, 18, 21; QS. Al-Mu'min ayat 54; dan al-Thalaq ayat 10 . Untuk mencapai kriteria ulul albâb ditetapkan beberapa insan ulul albâb, yaitu apabila santri telah memiliki identitas dan kepribadian sebagai manusia yang mempunyai ilmu pengetahuan luas, penglihatan yang tajam, otak yang cerdas, hati yang lembut dan semangat tinggi karena Allah. Identitas insan ulul albâb ini dapat dikenali melalui keluasan ilmu pengetahuan seseorang karena ia menganggap seluruh jenis ilmu pengetahuan itu bermanfaat bagi kehidupan. Orang yang memiliki ilmu pengetahuan yang luas akan memiliki semangat atau 
gairah untuk mempelajari berbagai ilmu pengetahuan untuk mengambil manfaatnya (adaptasi dari UIN Malang, 2010: 59). Berarti, konsep mukmin ulul albâb merupakan integrasi antara kekuatan wahyu dan kekuatan akal, atau dengan kata lain integrasi antara ilmu dan agama. Dengan demikian, insan ulul albâb adalah insan yang dalam dirinya terbina keimanan yang kokoh dan intelektualitas yang tinggi sehingga mampu menghasilkan gagasan baru yang kreatif, dinamis, dan inovatif untuk dapat diterjemahkan dalam bentuk amal saleh. Hal ini sejalan dengan firman Allah salah-satunya dalam QS. Ali Imran: 190-191.

Karakteristik mukmin ulul albâb sejalan dengan semangat Undang-Undang Nomor 20 Tahun 2003 tentang Sistem Pendidikan Nasional Pasal 3, yang menyatakan bahwa pendidikan nasional berfungsi: (a) mengembangkan kemampuan, (b) membentuk karakter, dan (c) membangun peradaban bangsa yang bermartabat dalam rangka mencerdaskan kehidupan bangsa. Karakter tersebut terkait dengan core values pesantren yakni menjunjung tinggi nilai; 1) tauhid, 2) martabat kemanusiaan, dan 3) memakmurkan lingkungan/alam semesta. Pendek kata, semua itu merupakan cermin dari karakter mukmin, muttaqin dan ulul albâb. Ciri-ciri ulul albâb adalah berakhlak mulia dan sehat (ziker), berilmu dan cakap (fiker), kreatif dan mandiri (dziker), serta menjadi warga negara yang baik dan bertanggung jawab (dqiker dan amal saleh).

Sebaran Karakter Mukmin Ulul Albâb dalam Kurikulum Pondok Pesantren Al Mukhlisin Mempawah Kalimantan Barat

\begin{tabular}{|l|l|c|c|c|c|}
\hline \multirow{2}{*}{ No. } & \multicolumn{1}{|c|}{ Komponen } & \multicolumn{4}{|c|}{ Mukmin Ulul albâb } \\
\cline { 3 - 6 } & $\begin{array}{c}\text { Iman/ } \\
\text { Mukmin }\end{array}$ & $\begin{array}{c}\text { Dzikir/ } \\
\text { Afektif }\end{array}$ & $\begin{array}{c}\text { Fikir/ } \\
\text { Kognitif }\end{array}$ & $\begin{array}{c}\text { Amal } \\
\text { Sholeh/ } \\
\text { Psikomotor }\end{array}$ \\
\hline A. & $\begin{array}{l}\text { Pengajian Kitab: } \\
\text { 1. Al-Qur'an }\end{array}$ & $\checkmark$ & $\checkmark$ & $\checkmark$ & $\checkmark$ \\
& 2. Hadis & $\checkmark$ & $\checkmark$ & $\checkmark$ & $\checkmark$ \\
& 3. Tauhid/Aqidah & $\checkmark$ & $\checkmark$ & $\checkmark$ & $\checkmark$ \\
& 4. Akhlak & $\checkmark$ & $\checkmark$ & $\checkmark$ & $\checkmark$ \\
& 5. Fiqih & $\checkmark$ & $\checkmark$ & $\checkmark$ & $\checkmark$ \\
& 6. SKI & $\checkmark$ & $\checkmark$ & $\checkmark$ & $\checkmark$ \\
\hline B. & Bahasa Arab & $\checkmark$ & $\checkmark$ & $\checkmark$ & $\checkmark$ \\
\hline C. & Muatan Lokal: & & & & \\
& 1. Kaligrafi & & $\checkmark$ & $\checkmark$ & $\checkmark$ \\
& 2. Tundang & & $\checkmark$ & $\checkmark$ & $\checkmark$ \\
\hline D. & Pengembangan Diri: & & & & \\
& 1. Seni Tilawah & $\checkmark$ & $\checkmark$ & $\checkmark$ & $\checkmark$ \\
& 2. Tahfidz & $\checkmark$ & $\checkmark$ & $\checkmark$ & $\checkmark$ \\
& 3. Qasidah dan Nasyid & $\checkmark$ & $\checkmark$ & $\checkmark$ & $\checkmark$ \\
& 4. Pidato 3 Bahasa & $\checkmark$ & $\checkmark$ & $\checkmark$ & $\checkmark$ \\
& 5. Khatib & $\checkmark$ & $\checkmark$ & $\checkmark$ & $\checkmark$ \\
& 6. Bilal & $\checkmark$ & $\checkmark$ & $\checkmark$ & $\checkmark$ \\
& 7. Fardhu Kifayah & $\checkmark$ & $\checkmark$ & $\checkmark$ & $\checkmark$ \\
\hline
\end{tabular}


(Sumber: Hasil observasi dan wawancara pada tanggal 5 Maret 2012 dengan pimpinan dan para asâtidz Pendipes Melayu al-Mukhlisin Mempawah Kalimantan Barat)

Ada penekanan atas pentingnya mengaktualisasi karakter "mukmin ulul albâb" dalam setiap mata pelajaran/pengajian kitab, bahkan muatan lokal dan pengembangan diri santri difokuskan ke dalam empat pilar yaitu mukmin, zikir, fikir, dan amal saleh. Aspek iman/mukmin santri dikembangkan untuk meningkatkan kekokohan aqidah. Zikir diarahkan pada pendalaman spiritual dan keagungan akhlak santri. Karakter/nilai yang dikembangkan pada aspek kedalaman spritual dilakukan melalui delapan cara, yaitu: 1) membiasakan shalat berjamaah, 2) membiasakan shalat tepat waktu, 3) membiasakan membaca bacaan shalat dengan benar, dan 4) membiasakan membaca al-Qur'an setiap Shalat Maghrib dan Isya. Nilai/karakter yang dikembangkan pada aspek keagungan akhlak meliputi: 1) akhlak kepada ibu dan bapak, 2) akhlak di masyarakat, 3) membiasakan bangun pagi, 4) disiplin, 5) kebersihan di rumah, pondok, masjid dan di masyarakat, 6) kebersamaan, 7) tanggung jawab, dan 8) menerima tamu. Fikir diarahkan untuk memperoleh ilmu pengetahuan seluasluasnya. Nilai/karakter keluasan ilmu dikembangkan melalui delapan cara, yakni: 1) mempelajari kitab kuning, 2) membiasakan santri ke perpustakaan, 3) kreatif, 4) belajar teratur setiap hari, 5) membaca al-Qur'an, 6) mempelajari Bahasa Arab, 7) mempelajari bahasa Inggris, dan 8) mengikuti pendidikan formal melalui jalur pendidikan madrasah dari jenjang Ibtidaiyah hingga ke Aliyah.

Pengembangan karakter/nilai santri pada kegiatan-kegiatan amal shaleh, meliputi: 1) budaya berbagi dengan sesama/sharing, 2) keterampilan menulis kaligrafi, 3) keterampilan tilawah, 4) keterampilan ceramah/kultum, 5) kebersihan, 6) gotong royong, 7) kebersamaan, 8) olah raga setiap hari minggu, 9) tugas piket, 10) melaksanakan pekerjaan (laporan dan PR) tepat waktu, 11) aktif belajar, 12) melaksanakan piket untuk melayani tamu, 11) kerja keras, 12) siddiq, 13) amanah, 14) tabligh, dan 15) fathanah.

Pondok Pesantren Melayu al-Mukhlishin Mempawah Kalimantan Barat mulai mengenal pendidikan karakter/nilai setelah mereka melakukan kegiatan studi banding ke Pondok Pesantren Daarut Tauhid Bandung. Mereka memahami pentingnya nilai/karakter baik melalui pemahaman tentang "manajemen qalbu".

Pola pengembangan karakter/nilai santri didasarkan pada tiga pilar lembaga pendidikan yaitu pesantren, keluarga, dan masyarakat. Menurut Zubaedi, pendekatan yang dilakukan dalam pendidikan karakter/nilai dapat melalui intervensi dan habituasi dengan menggunakan strategi makro dan mikro. Secara mikro pengembangan nilai/karakter dapat dibagi dalam empat pilar, yakni kegiatan belajar di kelas, penciptaan budaya sekolah, kegiatan ko kurikuler dan/atau ekstrakurikuler. Secara makro dapat melalui pendidikan keluarga di rumah, dan dalam masyarakat. Proses pendidikan karakter di sekolah saat ini terlalu menggunakan model pembelajaran yang didasarkan pada interaksi sosial (model interaksi) dan transaksi (Zubaedi, 2011: 199). 
Menurut Noeng Muhajir, pembelajaran karakter/nilai, dapat diselenggarakan dengan menggunakan pendekatan dogmatis, deduktif, induktif, dan/atau reflektif. Kirschenbaum mengemukakan bahwa indikator pembelajaran karakter/nilai yang komprehensif dapat ditinjau dari metode yang digunakan, tingkat partisipasi (guru, siswa dan orang tua), dan lembaga/konteks/tempat berlangsungnya pendidikan nilai/moral (sekolah, keluarga). Metode yang digunakan dapat berupa metode inkulkasi (inculcation), keteladanan (modeling), fasilitasi (facilitation), dan pengembangan keterampilan (skill building) (Zubaedi, 2011: 231 dan 232).

Melalui intervensi dikembangkan suasana interaksi belajar dan pembelajaran di antara para santri. Proses pembelajaran dilaksanakan di dalam kelas dan di luar kelas (keluarga dan masyarakat) yang dirancang untuk mencapai tujuan pembentukan karakter/nilai melalui pengajian kitab kuning dan bahasa Arab yang melibatkan/intervensi masyarakat umum. Tujuannya agar santri mendalami ajaran Islam dan menjadi ahli ilmu agama Islam yang dapat digunakan di masyarakat.

Proses habituasi dilakukan melalui melalui sejumlah pembiasaan yaitu: 1) shalat wajib berjama'ah, shalat tahajjud berjama'ah, shalat dhuha, dan membaca al-Qur'an bersama, 2) santri selalu diberi pesan dan diingatkan membiasakan berbakti kepada kedua orang tuanya, 3) menjunjung tinggi nilai kebersamaan, kebersihan, dan tanggung jawab, 4) mengembangkan sifat dan sikap santri yang santun dan bertatakrama baik, 5) menaati tata tertib pondok pesantren, 6) bangun sebelum subuh/pagi, dan 7) menghindari narkoba.

Proses pendidikan yang melibatkan orang tua santri dilakukan dalam pertemuan yang diselenggarakan setiap satu semester. Dalam pertemuan tersebut dikondisikan budaya sharing / tukar menukar, informasi, cara mengontrol santri dan upaya mengaktualisasi karakter santri baik di rumah maupun di masyarakat atau saat mereka pulang liburan sekolah/pengajian. Kegiatan sosial keagamaan di masyarakat dapat berupa menebas rumput di depan masjid, membersihkan masjid, pada musim hujan melakukan kegiatan gotong royong membersihkan selokan dan gorong-gorong yang melibatkan masyarakat sekitar dan pembinaan majelis taklim.

Model pembelajaran yang diinginkan Pesantren Melayu Al-Mukhlishin adalah holistik. Pesantren berupaya memberdayakan dan memanfaatkan semua lingkungan belajar yang ada untuk menyempurnakan dan menguatkan secara terus-menerus proses pendidikan karakter/nilai di pesantren. Pembelajaran kitab kuning dilaksanakan dengan menggunakan pendekatan terintegrasi dalam semua mata pelajaran Pendidikan Agama Islam (Al-Qur'an, Hadis, Aqidah/Tauhid, Fiqih, Akhlak, SKI, dan Bahasa Arab). Di lingkungan pesantren dibangun budaya pesantren yang positif (displin, tertib, sopan, santun, bersih, hidup bersama, dan religius. Budaya pesantren dapat tertanamkan pula melalui keteladanan pimpinan pondok, para asâtidø, keramahan masyarakat sekitar, kepedulian sosial para senior, kepedulian lingkungan para staf, dan rasa 
kebangsaan/tanggung jawab tokoh-tokoh masyarakat sekitar. Kegiatan kokurikuler yang berorientasi pada pembentukan karakter mukmin ulul albâb senantiasa diintegrasikan dengan praktik peribadatan seperti praktik mengurus jenazah ketika ada warga masyarakat yang meninggal dunia. Kegiatan ekstrakurikuler seperti olah raga (sportivitas) dan kepramukaan (nasionalisme) senantiasa mengintegrasikan diri dengan karakter mukmin ulul albâb.

Dalam teori kurikulum Tyler, Pesantren Al Mukhlisin Mempawah Kalimantan Barat mencoba menerapkan model pengembangan kurikulum kombinasi transmisi dan transaksi yang secara sekaligus melibatkan tujuan pembelajaran, masyarakat dan mata pelajaran. Kurikulum kontemporer senantiasa memperhatikan kehidupan yang juga kontemporer (Miller \& Seller, 1985: 210).

\section{Dimensi Sosial Kurikulum Pesantren Al Mukhlisin}

Kurikulum Pesantren Al Mukhlisis Tahun 2010, memuat karakter/nilai mukmin ulul albâb yang mencerminkan penanaman atas nilai-nilai sosial kemasyarakatan. Pesantren tersebut, kecuali berupaya mewujudkan pilar mukmin melalui pengintegrasian pengajian kitab ke dalam mata pelajaran keagamaan, juga mengintegrasikan antara teori dengan praktik ke dalam proses pembelajaran kitab kuning baik di kelas maupun di luar kelas dan mengintegrasikan komponen pengajian kitab kuning dengan muatan lokal dan pengembangan diri santri dalam konteks bermasyarakat.

Zikir merupakan upaya memperkokoh aqidah, memperdalam ruh spritual santri dan membentuk kepribadian santri sebagai mukmin yang kaffah. Dimensi sosial yang terbentuk adalah santri kecuali cenderung aktif dalam melaksanakan ibadah seperti tahajud dan shalat dhuha juga rajin melaksanakan shalat berjamaah sehingga dapat berbaur dengan masyarakat setempat. Fikir tercermin dari para santri yang mumpuni dalam menguasai materi PAI termasuk Fiqih Muamalah. Dampak sosialnya adalah meningkatkan rasa percaya diri santri karena merasa memiliki ilmu sebagai bekal untuk mengabdi kepada masyarakat. Amal saleh dibangun dari kemampuan santri dalam mempraktikkan ilmunya dengan berani tampil mengisi ceramah agama di radio, di masjid dan di masyarakat terutama pada perayaan peringatan hari-hari besar Islam.

Dimensi sosial (kemasyarakatan) membawa dampak pada masyarakat sekitar sehingga mereka terpacu untuk memasukkan anak mereka ke Pesantren Al Mukhlisin sehingga jumlah santri meningkat hingga 80\%. Dampak lain adalah meningkatnya permintaan masyarakat agar santri dapat memberikan bimbingan keagamaan kepada putra-putri mereka. Masyarakat sekitar pun semakin giat shalat berjamaah dan bersemangat mengikuti kegiatan majlis ta'lim yang diselenggarakan atas kerja sama pesantren dengan masyarakat. Desa Antibar (setempat) pun menjadi juara umum MTQ mulai tingkat desa, kecamatan hingga kabupaten, juara II pidato tingkat nasional pada tahun 2011, juara harapan untuk putra lomba bidang olah raga cabang atletik (lari $400 \mathrm{~m}$ ) di tingkat nasional tahun 
2011, dan lolos seleksi tujuh cabang Pospenas tingkat propinsi dan mengikuti Pospenas tingkat nasional yaitu ke Surabaya pada tahun 2010.

Dalam konteks kurikulum, dimensi sosial kurikulum Pesantren Al Mukhlisin Mempawah Kalimantan Barat ini mencoba mengaktualisasikan bidden curriculum yang tidak secara eksplisit dimaksudkan oleh guru. Guru tidak secara lisan harus menginstruksikan santri berbaur dengan masyarakat tetapi sistem pesantren senantiasa menyatu dengan masyarakat. Ada banyak hal yang tidak disadari oleh santri maupun guru bahwa masyarakat adalah kurikulum terbaik yang dapat direspons baik secara negatif maupun positif oleh lembaga pendidikan termasuk pesantren (Print, 1989: 5-8) .

\section{SIMPULAN}

Pola pengembangan kurikulum Pondok Pesantren Al Mukhlisin jika dikaji berdasarkan teori manajemen mutu pendidikan Juran meliputi; perencanaan, pengendalian, dan peningkatan mutu kurikulum. Penyempurnaan dan penyesuaian dilakukan terus-menerus guna mengikuti perkembangan zaman. Produk pengembangan kurikulum terwujud pada tahun 2010, namun belum terdokumentasikan dengan baik, belum memiliki tim khusus, dan belum mengacu pada KTSP. Pesantren belum pernah melakukan sosialisasi dan pemantapan Permendiknas Nomor 22, 23, dan 24 tahun 2006, tentang penyusunan KTSP berikut workshop, in house training dan pendampingan penyusunan KTSP untuk pesantren. Pengendalian mutu pengembangan kurikulum melibatkan langsung pimpinan pondok pesantren. Dalam struktur kurikulum hasil pengembangan, pengajian kitab kuning terintegrasi dengan komponen mata pelajaran PAI (al-Quran, Hadis, Tauhid/Aqidah, Akhlak, Fiqih, SKI, dan Bahasa Arab), muatan lokal dan pengembangan diri santri, dan terintegrasi dengan kegiatan kokurikuler dan ekstrakurikuler, dan proses pembiasaan di pesantren, keluarga/rumah, dan di masyarakat.

Kurikulum Pesantren Al Mukhlisin Mempawah Kalimantan Barat hasil pengembangan, secara terintegrasi memuat nilai/karakter "mukmin ulul albâb" yang bersumber dari al-Qur'an dan Hadis the golden rule dan sejalan dengan tujuan Sistem Pendidikan Nasional yang berdasar pada nilai moral universal.

Pola pengembangan karakter mukmin ulul albâb dalam struktur kurikulum hasil pengembangan mencakup; 1) aktualisasi karakter empat pilar (mukmin, zikir, fikir, dan amal saleh) mukmin ulul albâb ke dalam setiap mata pelajaran, pengajian kitab kuning, muatan lokal dan pengembangan diri santri, 2) implementasi pengalaman belajar santri dilakukan melalui proses pembudayaan dan pemberdayaan yang melibatkan tiga pilar/lingkungan pendidikan (pesantren, keluarga, dan masyarakat), dengan dua pendekatan yaitu intervensi dan habituasi. 3) pola pembelajaran pengajian kitab kuning sedemikian rupa terintegrasi dengan materi pendidikan agama Islam di madrasah dan persoalan-persoalan kemasyarakatan. 


\section{DAFTAR PUSTAKA}

Apendix ISO 8402 - 1986. Extracts.

Atmaja, Bagus Tris. 2010. Rekonstruksi Pendidikan Pesantren dengan Membangun Budaya Ilmiah dan Islamisasi Sains. Pesantren dan Peradaban Islam, Amien Haedari (Ed.) Jakarta: Puslitbang Pendidikan Agama dan Keagamaan, Balitbang dan Diklat Kementrian Agama RI.

Departemen Agama RI. 2007. Libat PP. No. 57 Tahun 2007, Bagian Kesatu, Pasal 14 ayat 3. Jakarta; Direktorat Pendidikan Diniyah dan Pondok Pesantren, Dirjend Pendidikan Islam.

Dhofier, Zamaakhsyari. Tradisi Pesantren: Studi tentang Pandangan Hidup Kiai.

Haedari, Amien (Ed.) Pesantren dan Peradaban Islam, Jakarta; Puslitbang Pendidikan Agama dan Keagamaan, Balitbang dan Diklat Kementerian Agama RI.

Juran, J.M. 1989. Juran On Quality by Design. Juran Institute Inc.

Miller, John P and Seller, Wayne, 1985. Curriculum Perspective and Practice. New York: Longman.

Muhtifah, Lailial. 2010. Sistem Penjaminan Mutu Pendidikan Berbasis Core Values Tarbiyab Ulul albâb, (Studi Kasus pada UIN Maliki Malang). Jakarta; SPS UIN Syarif Hidayatullah Jakarta. Disertasi, belum diterbitkan.

Muhaimin. 2010. Pengembangan Kurikulum Pendidikan Agama Islam di Sekolah, Madrasab dan PT. Jakarta: RajaGrafindo Persada.

Muhaimin. 2010. Arah Baru Pengembangan Pendidikan Islam, Pemberdayaan, Pengembangan Kurikulum bingga Redifinisi Islamisasi Ilmu Pengetabuan. Bandung: Nuansa.

Muhaimin. 2011. Pemikiran dan Aktualisasi Pengembangan Pendidikan Islam. Jakarta: Rajawali Press.

Philip, Tovey. 1994. Quality Assurance in Continuing Professional Education. LondonNew York: Routledge.

Peraturan Pemerintah RI No. 55 Tahun 2007 tentang Pendidikan Agama dan Pendidikan Keagamaan.

Print, Murray. 1989. Curriculum Development and Design. Wellington: Allen \& Unwin.

Rohiat. 2009. Manajemen Sekolah, Teori Dasar dan Praktik. Bandung: Refika Aditama.

Tim Pustaka Yustisia. 2007. Panduan Lengkap KTSP. Yogjakarta: Pustaka Yustisia. Yamin, Moh. 2009. Manajemen Mutu Kurikulum Pendidikan, Panduan Menciptakan Manajemen Mutu Pendidikan Berbasis Kurikulum yang Progressif dan Inspiratif. Yogjakarat: Diva Press.

Wilton, P.S. 1994. The Quality System Development Handbook, With ISO 9002, (Singapore: Prentice Hall.

Zubaedi. 2011. Desain Pendidikan Karakter, Konsepsi dan Aplikasinya dalam lembaga Pendidikan. Jakarta: Kencana. 